\title{
Perceptions and academic and professional aspirations of teachers-in-training: Gender barriers or possibilities?
}

\author{
María Dolores Hidalgo Ariza (iD) Juan Manuel Muñoz González(D), \\ Eva Francisca Hinojosa Pareja (D) \\ Universidad de Córdoba (Spain) \\ lola.bidalgo@uco.es,juan.manue@uco.es,ehinojosa@uco.es
}

Received March, 2020

Accepted September, 2020

\section{Abstract}

Purpose: This paper presents the results of the application of an adaptation of the "Perceived Barriers Questionnaire" (PBQ) (Rodríguez-Lajo, Vila \& Freixa, 2008) to identify if there are gender roles and stereotypes that influence the perceptions and future expectations, both in academic and the professional spheres, of teachers-in-training at the University of Córdoba.

Design/methodology: The sample of the study is composed of the students enrolled in the Social Education Degree and the Masters in Inclusive Education and Teaching Staff of Compulsory Secondary Education and Baccalaureate, Vocational Training and Language Teaching at the University of Córdoba. The questionnaire was administered to 157 students. The data were subjected to descriptive analysis, comparative means, correlational and regression analysis, study of internal consistency and factorial structure through exploratory and confirmatory factor analysis.

Findings: The results show, among other issues, some professional aspirations related to training rather than leadership, a greater fear of negative evaluation in women than in men and an important relationship between the perception of the gender role attributed to men and women in the workplace and their own aspirations and educational and professional expectations.

Research limitations/implications: The main limitation of the study s in its sample, as it is focused only on students of careers belonging to the field of Education Sciences and, specifically, at the University of Córdoba, so it would be interesting to carry out future studies with samples wider population.

Originality/value: This study aims to highlight the importance of detecting possible gender barriers during the training of educators to implement the necessary measures to promote true equality between women and men. In this sense, this research can be extrapolated to any educational environment, as well as work.

Keywords: Gender, Perceptions, Professional aspirations, Questionnaire, Higher Education

Jel Codes: $\mathrm{I} 23$ 


\section{To cite this article:}

Hidalgo Ariza, M.D., Muñoz González, J.M., \& Hinojosa Pareja, E.F. (2020). Perceptions and academic and professional aspirations of teachers-in-training: Gender barriers or possibilities?. Intangible Capital, 16(1), 31-42. https://doi.org/10.3926/ic.1638

\section{Introduction}

Numerous studies have provided evidence of the presence of both internal and external barriers associated to gender, which make difficult the educational and professional development of women in equal conditions and opportunities (Rodríguez, Vila \& Freixa, 2008; Donoso, Figuera \& Rodríguez Moreno, 2011; Porto, Cajide, Mosteiro, Castro, Sierra \& Rodríguez, 2012; Martínez \& Bivort, 2013; Castillo-Mayén \& Montes-Berges, 2014; Hidalgo, 2017). Most of these barriers are composed of different roles and gender stereotypes which are acquired throughout life from different social agents (the family, the school environment, the communication media...) (Colás \& Villaciervos, 2007), nurtured by a social, cultural, political and economic system that is androcentric and patriarchal. Larrieta, Velasco and Fernández (2015), and Contreras, Pedraza and Mejía (2012) have defined the following as the main barriers: the stereotypes associated to gender and the discrimination that comes from them, the roles and the segregated and hierarchal distribution of personal and professional responsibilities, the biased systems of selection and evaluation in the academic and professional spheres, the lack of female reference models, the exclusion of women in the informal social networks in the workplace, and the lack of flexibility in the structure and processes of the organization, which make difficult the reconciliation of personal and professional life.

Of all of these barriers, the present research study is focused on analyzing those that are perceived by university students, more specifically, future teachers, related to their academic and professional expectations and aspirations.

\subsection{Academic and professional aspirations of university students}

Concerning the academic and professional expectations, many authors indicate the presence of roles and stereotypes that determine the choice of career in a biased and discriminatory manner (Barberá, Candela \& Ramos, 2008; Rodríguez et al., 2008; García, Rebollo, Buzón, González-Piñal, Barragán \& Ruiz, 2010; Donoso et al., 2011).

The internalization of the differences in gender through the transmission of roles and stereotypes results in the establishment of differences in the comprehensive development and personal and professional options of university students. Boys and girls observe, from childhood, that expectations are placed on them, and based on these, they will act accordingly to receive the approval from others (Colás \& Villaciervos, 2007). As pointed out by Mosteiro and Porto (2017), when we do not behave according to our gender, as expected by society, the behaviors and actions are usually unapproved, rejected and criticized. Nevertheless, in the past few years, a change has been observed in the gender roles. For these authors, one of the causes is the growing level of education reached by women, being equal and even surpassing that of men. In this sense, the access of women to education, as well as the promotion of academic training, has favored their participation in the public arena and their promotion within the professional sphere. Even then, it is perceived that both male and female students have a stereotyped perception, as the choices they make still associate the men to the productive area, and the women to the reproductive one.

In that regard, Simón (2005) indicates that in the stage of puberty, the girls perceive that success and triumph are linked to beauty and sympathy, and not their intellectual or entrepreneurial spirit. If this is true, then they, although they may have a vocation or inclination towards other areas, tend to choose study subjects that are related with the area of Humanities and Social Sciences, linked to the service sector or caring of individuals, which have less prestige and lower pay. However, the men perceive that what is expected of them is to be strong, 
sporty, and smart, and independently of the results they obtain, tend to choose scientific or technological areas to obtain success and provide an answer to what society expects from them. Years after, Rodríguez and Megías (2015) still confirmed an attribution of stereotypes differentiated according to gender. Thus, characteristics such as sensibility, understanding, responsibility and prudence are associated to the female gender, while characteristics such as dynamism, functionality, action and prominence are associated to the male gender.

In this way, society promotes the idea that girls have characteristics such as a low self-esteem, dependence and insecurity, while it favors the idea that boys have a high self-esteem, independence and security, contributing to the maintenance of the patriarchal and androcentric system (Simón, 2005).

This set of characteristics, stereotypes, social expectations and distribution of roles, also have an effect on the making of decisions when having to choose a specific professional trajectory and the aspirations or expectations they have. These decisions are mediated by intrinsic factors, such as vocational maturity, which is achieved through an adequate self-concept, through self-knowledge and self-esteem (Martínez-Martínez, 2013). Other factors that condition the making of decisions are: the interests, the personality, the aptitude, the limitations, the hobbies, trends and personal tastes. Also, other extrinsic factors exist, such as: society, economics, job market, etc. All of these are affected by gender, as observed in the work by Miller, Eagly and Linn (2015), who attest that both girls and boys have stereotyped beliefs about professions, thinking that women have qualities for some professions, while men have other qualities.

Along the same line, other research studies have provided evidence that the male university students mainly value prestige, income, entrepreneurship and leadership; while the female students are more concerned with a good workplace environment, feeling useful, and being recognized by their female and male peers, as well as by those in charge in the company (Barberá, Ramos \& Candela, 2006; Olivares \& Olivares 2013; Pérez-Carbonell \& Ramos, 2015).

García, Padilla and Suárez (2009) justify the difference found in the choice of careers in that the professions themselves are stereotyped and the students correlate this gender-based classification with the courses from these careers. This is likewise confirmed in the work by Martínez and Bivort (2013), who confirm the existence of a career role that conditions their educational choices.

In the processes of selection and promotion created, evidence is provided about a double segregation: horizontal and vertical. Horizontal, as many areas of knowledge are feminized, such as Education, Health Sciences and Humanities (related with the care of people and social services), and, on the other hand, others are masculinized, such as Engineering, Sciences and Math (more technical and mechanical tasks). Also, we find a vertical segregation, as the number of women who occupy positions of responsibility are scarce, despite being sufficiently qualified for them. This vertical association is associated to the existence of a "glass ceiling", described by Guil (2016) as the barriers found by women for accessing higher positions, such as the difficulty in reconciling motherhood with the professional sphere, the family demands or the social expectations that define the adequate and accepted behaviors of women and men.

\section{Objectives}

The study presented addresses the following objectives:

1. To describe the perceptions of male and female teachers-in-training (students enrolled in the Social Education Degree), as well as postgraduate students (Masters in Inclusive Education, and Compulsory Secondary Education and Baccalaureate, Vocational Training and Language Teaching) at the University of Córdoba, related to their professional aspirations, the fear of a negative evaluation, and the perceptions of the gender roles of women and men in the workplace.

2. To analyze if there are differences in their perceptions as a function of their degree, type of access to the University, grade average in the academic records of their present studies, age, sex, current housing situation, level of education of the mother, current work status of the mother, level of education of the father, and current work status of the father. 
3. To observe the existence or not of relationships between the different dimensions of the questionnaire.

4. To determine if the professional aspirations of the students are explained by the fear of negative evaluation they observed, as well as their perceptions of the gender roles of men and women.

\section{Method}

A quantitative, descriptive and inferential approach was utilized for this study. A cross-sectional survey was utilized, as a set from a population was described in a specific moment in time, which allowed us to analyze the existence of differences between subgroups and to find the relationships between the variables studied.

\subsection{Sampling and participants}

The context of the study is framed within a broader research study aimed at the entire student body from the Faculty of Education at the University of Cordoba. This work, specifically, shows the results corresponding to teachers-in-training (students enrolled in the Social Education Degree and the Masters in Inclusive Education and Teaching of Compulsory Secondary Education and Baccalaureate, Vocational Training and Language Teaching) from this University. The sample selection was conducted by using non-probabilistic, convenience sampling (Cuenca \& Lozano, 2016), as the questionnaire could only be used with the groups of students whom the researchers had access to during academic year 2016-2017.

The sample was composed by a total of 157 students, corresponding to $36.76 \%$ of the population. Of this, 93 were enrolled in the Social Education Degree (59.2\%), 28 to the Masters in Inclusive Education (17.8\%), 36 to the Masters in Compulsory Secondary Education Teaching, Vocational Training and Language Teaching (22.9\%). This sample was primarily composed by women $(73.9 \%, \mathrm{n}=116)$, and with an age range between 18 and 26 years old or older, with the highest percentage found for the $18-23$ years old group $(58.6 \%, \mathrm{n}=92)$.

\subsection{Data collection instrument}

The instrument chosen for the present research is an adapted version (Hidalgo, 2017) of the Perceived Barriers Questionnaire (PBQ) (Rodríguez et al., 2008), initially designed by the DONA/GREDI group within the research framework financed by the Institut Català de les Dones "Gender barriers in the development of a university woman: The invisible filter".

In its latest version, it is an anonymous questionnaire administered online containing close-ended, polythematic questions, and with a Likert response scale with five options, from complete disagreement (1) to complete agreement (5) for the dimensions "Professional aspirations" and "Fear of negative evaluation"; and from none (1) to a lot (5) for the dimensions "Perceptions of the gender role of women in the workplace" and "Perception of the gender role of men in the workplace". It includes independent variables from the education sphere (degree, access to the university, and average grades), sociodemographic data (age, sex and current living situation), and family data (level of studies and work status of the father and mother). It is comprised by 63 items presented as statements and structured in four dimensions:

- Professional aspirations: It encompasses items that refer to the commitment with a professional project, to the meaning given to work success, the personal involvement and the time invested for the achievement of professional objectives, the intention of ascending in the professional career, and being recognized as a leader in the workplace.

- Fear of a negative evaluation: A dimension of 9 items that refer to the rejection of the evaluations from other people, concern, negative expectations or anguish towards negative evaluations from others.

- Perception of gender role (two-sided dimension: women and men in the workplace): The same items appear in both dimensions (19 in each case), which refer to issues such as planning ability, self-control, assumption of responsibilities, emotional stability, interpersonal communication, facing risks, conciliation, urge to excel, or self-esteem. 
The validity and reliability of the adaptation of the instrument were measured with different statistical analyses. In first place, for the validity of the construct, an exploratory factorial analysis (EFA) was performed with the Factor Analysis version 10.8 program. The method by Hull (Lorenzo-Seva, Timmerman and Kiers, 2011) was utilized, along with the process of extraction of common factors "unweighted least squares" (ULS), considering the "Weighted Oblimin" rotation (Lorenzo-Seva, 2000), whose Kaiser-Meyer-Olkin (KMO) index was 0.88, its Bartlet'sspherericity test was $\mathrm{p}=0.000$, and its Root Mean Square Residual (RMSR) $=0.0498$, were considered adequate for the model (Aldas \& Uriel, 2017). The result of the extraction of the principal components showed the existence of 4 factors, where the total explained variance was 47.405 , revealing an appropriate equilibrium between the components of the instruments, which were representative of the theoretical concept.

To compare and confirm the model extracted through the EFA, a Confirmatory Factor Analysis (CFA) was performed with the statistical program AMOS, version 23. The results obtained, through the use ofthe relativelyadjusted values from the discrepancy function (chi-square), as well as those based on the root mean square error of approximation (RMSEA), showed adequate indices of adjustment as a function of the model $(\chi 2=2472.860$, gl. $=1581 ; \mathrm{NFI}=.917$; RFI $=.897$; IFI $=.968 ; \mathrm{TLI}=.960 ; \mathrm{RMSEA}=.023)$. Therefore, the model was accepted, using as the basis the AFE results and the theoretical dimensions considered within them (Schumacker \& Lomax, 2004; Browne \& Cudeck, 1993; Byrne, 1994; Hu \& Bentler, 1998; Steiger, 2000).

The measurement of the reliability of the instrument was performed through an internal consistency approach (Merino-Soto, 2016), obtaining a Cronbach's alpha of 0.91, which reflects the high reliability of the items from the questionnaire. Likewise, through the application of these analyses to the different factors, the coefficients obtained were adequate: 1. Professional aspirations $(\alpha=.83)$; 2. Fear of negative evaluation $(\alpha=.92)$; 3. Perception of the gender role of women in the workplace $(\alpha=.89)$, and 4 . Perception of the gender role of men in the workplace $(\alpha=.89)$. Lastly, in regard to the normality of the sample, it should be pointed out that the variance had a normal distribution, as measured by the Kolmogorov-Smirnov test $(\mathrm{p}=.200)$.

\subsection{Procedure}

The instrument was provided online, and could be completed in-person in the classroom, or virtually from home whenever the students chose to do so. The procedure was monitored by the researchers, so that they could detect difficulties in comprehension, and so that the doubts could be answered during its completion. For this, a member of the team was present in each of the courses and groups to present the study and the instrument, to ensure the anonymity and the confidentiality of the treatment of the data, as well as to solve the difficulties that may appear.

\subsection{Data analysis}

The analyses conducted in this study were the following:

- Basic descriptive analysis according to dimension.

- Analysis of variance as a function of the education (degree, year, type of access to the university, and grade average), sociodemographic (age, sex, and current living conditions), and family (education level and current work status of the father and mother) variables. For this, the Student's $t$ test and ANOVA were performed, with the statistical package SPSS 23.

- Relational study between the dimensions through bivariate correlations.

- Multiple linear regressions to predict the professional aspirations of the students as a function of the fear of negative evaluations, as well as the perceptions of the gender roles of women and men.

\section{Results}

Next, the results derived from the application of the instrument as a function of the type of analysis are presented: the descriptive statistics and the analysis of variance are presented according to dimensions, while the correlation and regression analyses are presented in two different sections. 


\subsection{Professional aspirations of the university students}

This dimension combined 16 items which alluded to the perceptions of the students in regard to their professional aspirations. More specifically, it mentioned aspects such as their dedication to their work, the importance given to training, planning or leadership, among others.

In the results obtained in this dimension, it was observed that in general, the students were partially in agreement with the professional aspirations included in the instrument $(\mu=4.45 ; 6=.55)$. Among them, we found that the items related with leadership and professional success obtained average scores that were lower than those that referred to the importance given to training, expertise or perseverance. Proof of this was shown by the items that obtained a lower mean score, which referred to "when I become established in my career, I would like to direct other employees" ( $\mu=3.28)$, and that "professional success is fundamental if one wants to feel truly happy" ( $\mu=3.39$ ), about which those polled were mostly indifferent. While the items with higher mean scores corresponded with "continuing my training to achieve new objectives" ( $\mu=4.59)$, and with the aim of "becoming an expert in my field of work" ( $\mu=4.46)$.

As for the differences according to gender, related to the opinions of the students with respect to their professional aspirations, the Student's $t$ test for independent samples pointed out that statistically significant differences did not exist. On the other hand, to determine the relationship of the degree, type of access to the university, level of education of the mother, work status of the mother, level of education of the father, and work status of the father, with the professional aspirations of the students, multiple comparisons of the means were performed with an ANOVA. The results obtained showed that there were no statistically significant differences between any of the variables considered and the professional aspirations of the students.

\subsection{Fear of a negative evaluation}

This dimension was composed by 9 items which showed the perceptions of both female and male students about their relationship with the concern about the image that others in their surroundings have of them and of themselves. More specifically, these items referred to the evaluations related with the impressions, defects, or mistakes, among others.

In the results obtained in this dimension, it was observed that the students were mostly indifferent with respect to the fear of a negative evaluation $(\mu=2.91 ; \sigma=.82)$. Within this indifference, the issues that were of greater concern to them referred to "that people have a bad impression about me" $(\mu=3.24)$, and "I worry about saying or doing the wrong things" ( $\mu=3.22$, while the most important disagreement was found in aspects such as "I am afraid that people will notice my defects" ( $\mu=2.55)$ or "I worry that people will find faults (or mistakes) in me" $(\mu=2.57)$.

Just as in the previous dimension, we analyzed the relationship found between gender and the variation of responses about the fear of a negative evaluation, through the Student's t test. In this sense, the test indicated the existence of statistically significant differences $(T=-2.137, \mathrm{p}=.036)$. The mean value for the girls was significantly higher than the boys, which provided evidence of the fear of a negative evaluation, which was higher in general (2.99 vs. 2.67). With respect to the variation of the responses, as a function of the degree, type of university access, average grades in their academic records of their current studies, age, way of life, level of education of the mother, works status of the mother, level of education of the father, and work status of the father, with the fear of a negative evaluation, multiple comparisons of the mean were also performed with an ANOVA. In all the cases, the results obtained showed that there were no statistically significant differences.

\subsection{Perception of the gender role of women in the workplace}

This dimension combined 19 items which alluded to the opinions of the students with respect to the characteristics attributed to women in the context of work. More specifically, it referred to characteristics such as planning ability and self-control, assumption of responsibilities, urge to excel and expectations of work and professional success, among others. In the results obtained, it was observed that the students were generally in 
agreement with attributing the characteristics in the dimension to women $(\mu=4.10 ; \sigma=.52)$. The characteristics that were strongly attributed were, with mean values between 4.41 and 4.26 , related with the satisfaction, dedication, and excelling at work ("satisfaction with work well done", "urge to excel at work", "time dedicated to work"), and with collaboration and care of other people ("collaboration with their peers" and "time spent caring for the family and the home"). On the other hand, the characteristics attributed to a lesser degree to women in the workplace mainly referred to self-esteem $(\mu=3.57)$, confidence in their own competencies $(\mu=3.76)$, control of emotions ("emotional stability", $\mu=3.64$, and "mechanisms of self-control" $\mu=3.76$ ), the value given to prestige and power within the organization $(\mu=3.62)$, and that they "more frequently accept lowerpaying jobs" $(\mu=3.78)$.

On the other hand, the Student's t test performed to identify possible differences related to the student's gender in regard to their perception of the gender role of women in the workplace, did not find statistically significant differences. No differences were found as a function of the other variables analyzed with the ANOVA either, providing evidence that neither the degree, type of access to the University, grade average, age, way of life, level of education, nor the work status of the parents, were related to this variability in the responses provide for this dimension.

\subsection{Perception of gender role of men in the workplace}

This dimension included the same items mentioned in the previous section. The results obtained showed that the students were greatly in agreement with the fact that the characteristics included in this dimension were present in men $(\mu=3.81 ; \sigma=.51)$. More specifically, the characteristics that were greatly attributed to men were related with "satisfaction with work well done" $(\mu=4.13)$, and the "urge to succeed at work" ( $\mu=4.16)$, both of which coincided with the gender role of women. Also, in this case, we also found the "expectations of work or professional success" ( $\mu=4.13)$ as an important characteristic. On their part, the characteristics that the students attributed to men in the workplace, to a lesser degree, coincided in part with those that were associated to a greater degree to women: "work and family reconciliation" $(\mu=3.15)$, "time spent caring for the home and family" ( $\mu=2.97)$, and "more frequently accept lower-paying jobs" $(\mu=2.57)$.

As in the previous dimension, statistically significant differences were not found in the variability of the responses as a function of the different independent variables considered.

\subsection{Correlational study}

The following section addresses the correlational study between the 4 dimensions of the questionnaire. The resulting data on the application of Pearson's correlation can be observed in the following table (see Table 1).

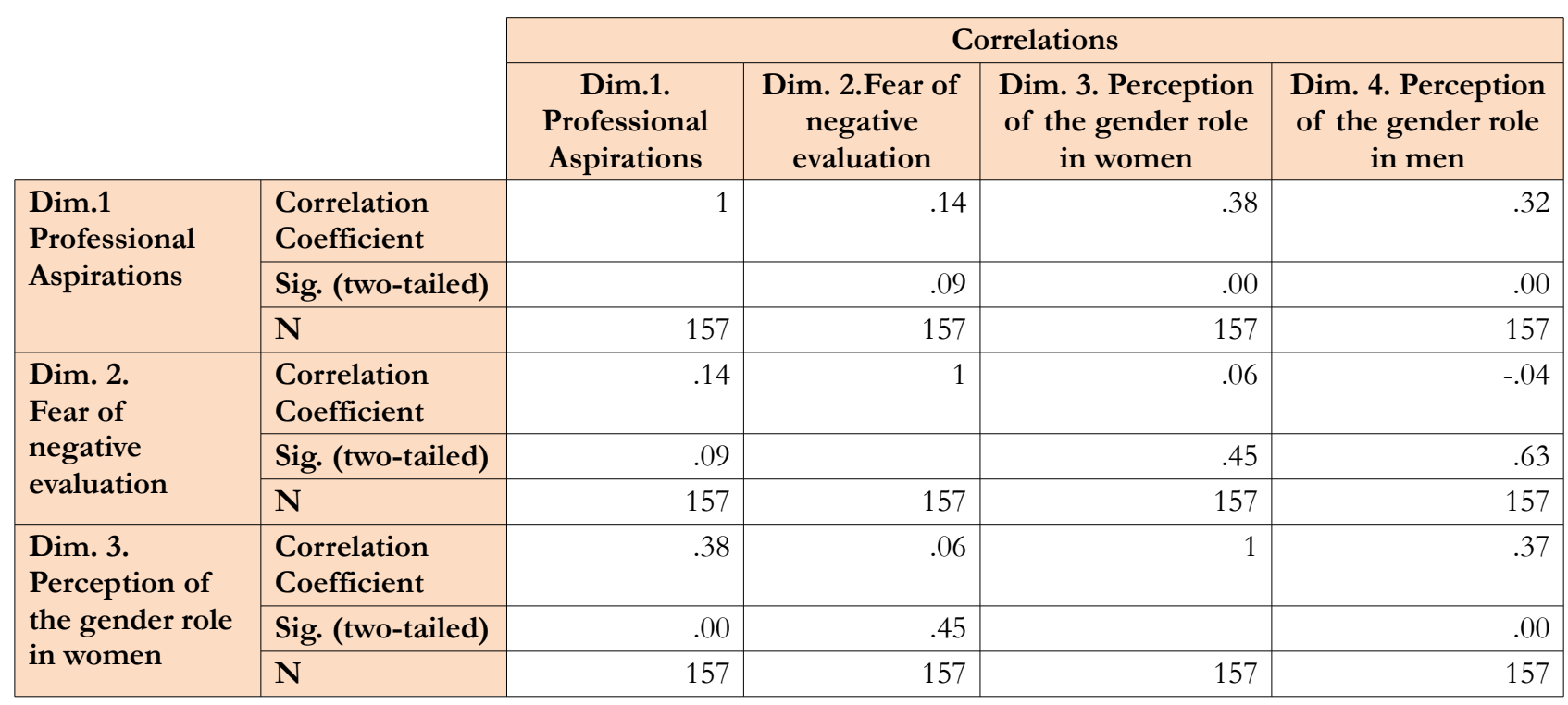




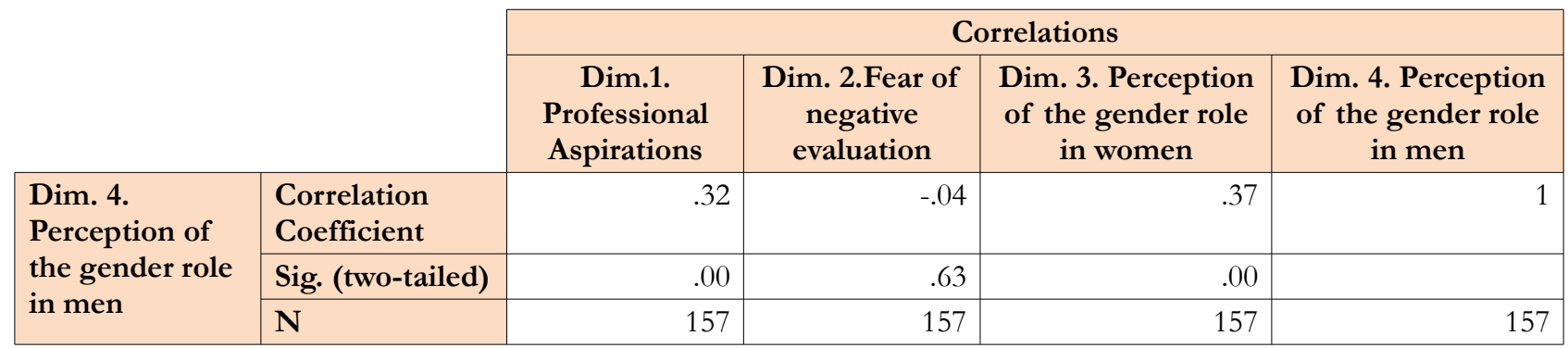

**. The correlation is significant at 0.01 (two-sided)

Table 1. Results of the bivariate correlations of the dimensions from the Perceived Barriers Questionnaire

As a function of the data obtained, it was verified that there was a relationship between dimension 1 , corresponding to the professional aspirations of the students, with dimension 3, which referred to the perception of the gender role of women in the workplace $(\mathrm{r}=.38, \mathrm{p}<.01)$; and dimension 4 , which alluded to the perception of the gender role of men in the workplace $(\mathrm{r}=.32, \mathrm{p}<.01)$. Also, a relationship was found between these last two dimensions, dimensions 3 and $4,(\mathrm{r}=.37, \mathrm{p}<.01)$, given that there was a two-tailed significance at $\mathrm{n} . \mathrm{s}=0.01$. The relationships established between the 3 dimensions mentioned was moderate, as pointed out by Mateo (2004) and Pérez, García, Gil and Galán (2009).

Lastly, it should be indicated that dimension 2, which referred to the fear of a negative evaluation of the students, was not correlated with any of the other 3 dimensions of the questionnaire.

\subsection{Explanatory models of the professional aspirations of the students as a function of the fear of a negative evaluation, as well as the perceptions of gender role of women and men in the workplace}

Once the relationship between the different dimensions of the questionnaire was made evident, whether or not these relationships could work as explanatory models of the dimension "Professional aspirations", was studied. For this, multiple linear regressions were performed as a function of "Fear of a negative evaluation", and the "Perceptions of gender role of men and women in the workplace". The resulting data showed, as foreseen from previous studies, that the "Fear of a negative evaluation" did not provide an explanation for the variability of the student's responses about their "Professional aspirations", while the "Perceptions of gender role of women and men" did result in significant results, as shown below.

\begin{tabular}{|c|c|c|c|c|c|c|c|c|}
\hline \multicolumn{9}{|c|}{ Coefficients $^{\mathrm{a}}$} \\
\hline \multirow{2}{*}{\multicolumn{2}{|c|}{ Model }} & \multicolumn{2}{|c|}{$\begin{array}{c}\text { Non-standardized } \\
\text { coefficients }\end{array}$} & \multirow{2}{*}{$\begin{array}{c}\begin{array}{c}\text { Standardized } \\
\text { coefficients }\end{array} \\
\text { Beta }\end{array}$} & \multirow[b]{2}{*}{ t } & \multirow[b]{2}{*}{ Sig. } & \multicolumn{2}{|c|}{$\begin{array}{l}\text { Collinearity } \\
\text { statistics }\end{array}$} \\
\hline & & B & $\begin{array}{c}\text { Standard } \\
\text { error }\end{array}$ & & & & Tolerance & VIF \\
\hline \multirow[b]{2}{*}{1} & (Constant) & 2.82 & .32 & & 8.81 & .00 & & \\
\hline & $\begin{array}{l}\text { Dim. 3. Perception of the } \\
\text { gender role in women }\end{array}$ & .37 & .07 & .38 & 5.13 & .00 & 1.00 & 1.00 \\
\hline \multirow{3}{*}{2} & (Constant) & 2.24 & .38 & & 5.81 & .00 & & \\
\hline & $\begin{array}{l}\text { Dim. 3. Perception of the } \\
\text { gender role in women }\end{array}$ & .29 & .08 & .30 & 3.86 & .00 & .86 & 1.16 \\
\hline & $\begin{array}{l}\text { Dim. 4. Perception of the } \\
\text { gender role in men }\end{array}$ & .22 & .08 & .21 & 2.63 & .01 & .86 & 1.16 \\
\hline
\end{tabular}

a. Dependent variable: Dim.1 Professional aspirations

Table 2. Coefficients of the regression line for the dependent variable "Professional aspirations of the students" as a function of the measurements from the dimensions Perception of the gender role of women and men in the workplace"

The results obtained, as shown in Table 2, allow us to observe that the dimensions "Perception of the gender role of women and men in the workplace", respectively, were predictive factors of the dimension "Professional 
aspirations of the students", as $\beta=.30, \mathrm{t}(303)=3.86, \mathrm{p}<.01$; and $\beta=.21, \mathrm{t}(207)=2.63, \mathrm{p}<.01$, respectively. In this sense, the adjusted R2 value was .171 , indicating that a total of $17.1 \%$ of the variability of the dimension "Professional aspirations of the students" was explained by the two variables cited previously.

\section{Discussion and conclusions}

Next, the conclusions derived from the study will be detailed, starting with the objectives set in the methodological design, including a discussion of the results found according to the theory presented.

The teachers-in-training manifested educational and professional aspirations that were more focused on increasing their training to become experts in their workplace than in leadership. Although a certain relationship could be established from the start between this trend in their expectations with the increased feminization of this field of study and a limited motivation of the women to play leadership roles (Gutierrez, 2015), it is true that both men and women converged in their responses, without statistically significant differences found between both collectives.

However, differences were found in the fear of a negative evaluation. In this dimension, the scores were significantly higher for the women, evidencing that they were more afraid of being negatively evaluated as opposed to the men. This difference could provide evidence of a greater concern and insecurity in the case of the women in this study. The GEM Spain report (Peña, Guerrero \& González-Pernía, 2017) also pointed to the same direction, providing evidence that the men had less fear of failure than the women, and the men who had been entrepreneurs perceived greater opportunities to undertake new projects, as they had more models to refer to and less worry about failing.

This distance between women and men could be related to the influence of the patriarchal and androcentric society in the shaping of our identity and the characteristics we assume as our own, favoring, in this case, a greater self-esteem, security and independence for men, and a greater dependency and insecurity for women (Simón, 2005). In fact, in this sense, in their work, Sánchez et al. (2011) pointed out the existence of a greater quantity of gender stereotypes in men than in women, and a belief of a certain superiority of the men, which negatively influences the women's self-esteem.

These findings are highly related with the perceptions shown by the students about the gender role of women and men in the workplace. Although in both cases characteristics such as excelling or satisfaction with work well done was attributed to both, observable differences were found in the characteristics related with a good selfesteem, self-control and confidence in oneself, which were more related to men than to women. At the same time, the elements linked with the care of other people and collaboration, as well as accepting more precarious conditions at work and less recognition, were found to be more present in women, while the expectations of success at work were greatly attributed to the men.

These results showed attributions that were even more stereotyped, along the same line as results from other studies (Barberá et al., 2008; Rodríguez et al., 2008; García et al., 2010; Donoso et al., 2011), although these did not wholly agree with the results from other works such as the one from Castillo-Mayén and Montes-Berges (2014), who attested that some stereotypes that were traditionally associated to the gender had now disappeared. Also, this trend was shown to be greatly generalized in the students surveyed, as no differences were found that related these associations of characteristics with the student's gender, their level of education, degree, academic records, or work status of their fathers and mothers. It is also true, however, as indicated by García-Retamero, Müller and López-Zafra (2009) or Eagly, Wood and Johannesen-Schmidt (2004), that roles and their stereotypes associated to genders vary through time and from one context to another, thus finding themselves in a dynamic and changing process. It is a complex, slow and non-linear process that is influenced by multiple factors that are social and cultural in nature.

Lastly, the correlation and regression analyses pointed out that the set of characteristics perceived by the students associated to the gender role of men and women in the workplace, could greatly explain, as opposed to the fear of a negative evaluation, how they perceived their own professional aspirations. This finding corroborated that in 
the case of the students surveyed, the educational and professional options were even more generalized, and in certain manner, were predicted by the differential characteristics they reflected upon and attributed to the different genders, and which also reflect the biased social and work destinies.

The research study also found some limitations, such as the sampling differences between the university Degree students and Master's students, which invites us to increase the sample, as well as the Degrees of the study participants. Another limitation was due to the use of instruments that were exclusively quantitative. This drives us to delve into the use of different research methods, techniques and instruments that are more qualitative in nature. Their use could allow delving into the meanings provided by the students to the perceptions observed, as well as the relationship established between them, and the educational and professional trajectories they will decide upon once their training has ended.

\section{Declaration of Conflicting Interests}

The authors declared no potential conflicts of interest with respect to the research, authorship, and/or publication of this article.

\section{Funding}

The authors received no financial support for the research, authorship, and/or publication of this article.

\section{References}

Aldas, J., \& Uriel, E. (2017). Análisis multivariante aplicado con R. Madrid: Paraninfo.

Barberá, E., Ramos, A., \& Candela, C. (2006). Mercado laboral y estereotipos de género. Revista de Psicología Social Aplicada, 16(1-2), 165-179.

Barberá, E., Candela, C., \& Ramos, A. (2008). Elección de carrera, desarrollo profesional y estereotipos de género. Revista de Psicología Social, 23(2), 275-285. https://doi.org/10.1174/021347408784135805

Browne, M.W., \& Cudeck, R. (1993). Alternative ways of assessing model fit. In K. A. Bollen \& J. S. Long (Eds.), Testing structural equation models (pp. 136-162). Newsbury Park, CA: Sage.

Byrne, B.M. (1994). Structural equation modeling with EQS and EQS/Windows. Thousand Oaks, CA: Sage Publications.

Castillo-Mayén, R., \& Montes-Berges, B. (2014). Análisis de los estereotipos de género actuales. Anales de Psicologia, 30(3), 1044-1060. https://doi.org/10.6018/analesps.30.3.138981

Cuenca, A., \& Lozano, S. (2016). La enseñanza de la investigación. Diálogo entre la teoría y el oficio del investigador en Trabajo Social. La Plata: Editorial de la Universidad Nacional de La Plata (EDULP). https://doi.org/10.35537/10915/53689

Colás, P., \& Villaciervos, P. (2007). La interiorización de los estereotipos de género en jóvenes y adolescentes. Revista de Investigación Educativa, 25(1), 35-58.

Contreras, F., Pedraza, J., \& Mejía, X. (2012). La mujer y el liderazgo empresarial. Revista Diversitas: Perspectivas en Psicología, 8(1), 183-194. https://doi.org/10.15332/s1794-9998.2012.0001.12

Donoso, T., Figuera, P., \& Rodríguez-Moreno, M.L. (2011). Barreras de género en el desarrollo profesional de la mujer universitaria. Revista de Educación, (355), 187-212.

Eagly, A.H, Wood, W., \& Johannesen-Schmidt, M.C. (2004). Social role theory of sex differences and similarities: Implications for the partner preferences of women and men. En A. H. Eagly, A. E Beall, y R. J. Sternberg (Ed.), The Psychology of Gender (pp. 269-295). Nueva York: Guilford.

García-Retamero, R., Müller, S., \& López-Zafra, E. (2009). Sobre la maleabilidad de los estereotipos de género: Influencia del tamaño de la población y el paso del tiempo en la percepción de hombres y mujeres. En J. TousPallarès \& J. M. Fabra Sopeña (Ed.), Actas del XI Congreso Nacional de Psicología Social (pp. 151-155). Tarragona: Universitat Rovira i Virgili. 
García, R., Rebollo, M.A., Buzón, O., González-Piñal, R., Barragán, R., \& Ruiz, E. (2010). Actitudes del alumnado hacia la igualdad de género. Revista de Investigación Educativa, 28(1), 217-232.

García, S., Padilla, M.T., \& Suárez, M. (2009). Los intereses académicos y profesionales de chicas que finalizan la escolaridad obligatoria. Revista de Educación, (349), 311-334.

Guil, A. (2016). Techos universitarios de cristal blindado. Investigaciones Feministas, 7(2), 25-39. https://doi.org/10.5209/INFE.53964

Gutiérrez, O. (2015). Estudios de liderazgo de hombres y mujeres. Revista Politica y Estrategia, (126), 13-35.

Hidalgo, M.D. (2017). Influencia de los roles y estereotipos de género en las percepciones y expectativas académicas y profesionales del alumnado universitario (Tesis doctoral). Universidad de Córdoba, Córdoba.

Hu, L.T., \& Bentler, P.M. (1995). Evaluating model fit. In R. H. Hoyle (Ed.), Structural equation modeling: Concepts, issues, and applications (pp. 76-99). Thousand Oaks, CA: Sage.

Larrieta, I., Velasco, E., \& Fernández, S. (2015). Las barreras en el acceso de las mujeres a los puestos de decisión: Una revisión de la situación actual y de las principales aportaciones de la literatura. Revista de Dirección y Administración de Empresas, (22), 1-23.

Lorenzo-Seva, U. (2000). The weighted oblimin rotation. Psychometrika, 65, 301-318. https://doi.org/10.1007/BF02296148

Lorenzo-Seva, U., Timmerman M.E., \& Kiers, H.A.L. (2011). The Hull Method for Selecting the Number of Common Factors. Multivariate Behavioral Research, 46(2), 340-364. https://doi.org/10.1080/00273171.2011.564527

Mateo, J. (2004). La investigación 'ex post-facto'. In R. Bisquerra, (coord.), Metodología de investigación educativa (pp. 196-230). Madrid: La Muralla.

Martínez, S., \& Bivort, B. (2013). Los estereotipos en la comprensión de las desigualdades de género en educación, desde la psicología feminista. Psicologia y Sociedade, 25(3), 549-558. https://doi.org/10.1590/S010271822013000300009

Martínez-Martínez, A. (2013). La Orientación como actividad educativa y vocacional en los itinerarios curriculares del alumnado de Bacbiller y Formación Profesional y su inclusión en el mercado laboral (Tesis doctoral). Granada: Universidad de Granada.

Merino-Soto, C. (2016). Diferencias entre coeficientes alfa de Cronbach, con muestras y partes pequeñas: Un programa VB. Anales de Psicología, 32(2), 587-588. https://doi.org/10.6018/analesps.32.2.203841

Miller, D.I., Eagly, A.H., \& Linn, M.C. (2015). Women's Representation in Science Predicts National GenderScience. Stereotypes: Evidence From 66 Nations. Journal of Educational Psychology, 107(3), 631-644. https://doi.org/10.1037/edu0000005

Mosteiro, M.J., \& Porto, A.M. (2017). Análisis de los Estereotipos de Género en alumnado de Formación Profesional: Diferencias según sexo, edad y grado. Revista de Investigación Educativa, 35(1), 151-165. https://doi.org/10.6018/rie.35.1.257191

Olivares, M.Á., \& Olivares, C. (2013). Impacto de los estereotipos de género en la construcción de la identidad profesional de estudiantes universitarios. REOP, 24(1), 121-131.

https://doi.org/10.5944/reop.vol.24.num.1.2013.11275

Peña, I., Guerrero, M., \& González-Pernía, J.L. (2017). GEM, Global Entrepreneurship Monitor. Informe España. Santander: Universidad de Cantabria. https://doi.org/10.22429/Euc2016.010

Pérez, R., García, J.L., Gil, J.A., \& Galán, A. (2009). Estadística aplicada a la Educación. Madrid: Pearson Prentice Hall.

Pérez-Carbonell, A., \& Ramos, G. (2015). Preferencias de los y las estudiantes universitarias sobre el empleo desde una perspectiva de género. Revista Complutense de Educación, 26(3), 721-739.

https://doi.org/10.5209/rev_RCED.2015.v26.n3.44804 
Porto, A.M., Cajide, J., Mosteiro, M.J., Castro, M.D., Sierra, S., \& Rodríguez, S. (2012). Estereotipos de género ante la ciencia y la tecnología del alumnado de formación profesional. En E. Pérez, J. C. Toscano, C. Flecha, A. Guil, O. Macías, y M.E. Pinero (Ed.), IX Congreso Iberoamericano de Ciencia, Tecnología y Género (pp. 1-14). Sevilla: Universidad de Sevilla.

Rodríguez, E., \& Megías, I. (2015). ¿Fuerte como papá? ¿ Sensible como mamá? Identidades de género en la adolescencia. Madrid: Centro Reina Sofía sobre Adolescencia y Juventud.

Rodríguez, M., Vila, R., \& Freixa, N. (2008). Barreras de género y actitudes hacia las redes sociales en alumnado universitario de las Facultades de Educación. Revista de Investigación Educativa, 26(1), 45-72.

Sánchez, M., Suárez, M., Manzano, N., Oliveros, L., Lozano, S., Fernández, B. et al. (2011). Estereotipos de género y valores sobre el trabajo entre los estudiantes españoles. Revista de Educación, (355), 331-354.

Schumacker, R.E., \& Lomax, R.G. (2004). A beginner's guide to structural equation modeling (Second edition). Mahwah, NJ: Lawrence ErlbaumAssociates. https://doi.org/10.4324/9781410610904

Simón, E. (March, 2005). Entre desigualdades y diferencias. Jornada de trabajo con el profesorado de las escuelas piloto del Proyecto NAHIKO, Vitoria-Gasteiz. Retrieved from: http://www.emakunde.euskadi.eus/contenidos/informacion/proyecto nahiko formacion/eu def/adjuntos/ELENA $\% 20$ SIMON $\% 20$ Entre $\% 20$ desigualdades $\% 20 \mathrm{y} \% 20$ diferencias.pdf

Steiger J.H. (2000). Point estimation, hypothesis testing and interval estimation using the RMSEA: Some comments and a reply to Hayduk and Glaser. Structural Equation Modeling, 7, 149-162.

https://doi.org/10.1207/S15328007SEM0702_1

Intangible Capital, 2020 (www.intangiblecapital.org)

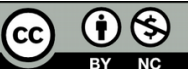

Article's contents are provided on an Attribution-Non Commercial 4.0 Creative commons International License. Readers are allowed to copy, distribute and communicate article's contents, provided the author's and Intangible Capital's names are included. It must not be used for commercial purposes. To see the complete license contents, please visit https://creativecommons.org/licenses/by-nc/4.0/. 